\title{
GYRINICOLA CHABAUDI ARAUJO \& ARTIGAS, 1982 (NEMATODA: PHARYNGODONIDAE) IN TADPOLES OF SCINAX NASICUS (COPE, 1862) (ANURA: HYLIDAE) FROM CORRIENTES, ARGENTINA
}

\author{
Cynthya E. GonZÁLEZ(1) y Monika I. HAMANN(1)
}

The females of Gyrinicola chabaudi Araujo \& Artigas, 1982 were originally described from tadpoles of Leptodactylus ocellatus (Linnaeus, 1758) captured in Santo Amaro, São Paulo, Brazil (Araujo and Artigas, 1982). The males were described upon specimens collected from tadpoles of Scinax ruber (Laurenti, 1768) (= Ololygon rubra Fouquette and Delahoussaye, 1977) and Chaunus crucifer (Wied-Neuwied, 1821) (= Bufo crucifer Wied-Neuwied, 1821) (Souza-Júnior et al., 1991). A redescription of $G$. chabaudi was made with specimens collected from different hosts, S. ruber, Chaunus crucifer, C. schneideri (Werner, 1894) (= Bufo schneideri Werner, 1894), Physalaemus sp., Rana catesbeiana Shaw, 1802, Hypsiboas geographicus (Spix, 1824) (= Hyla geographica Spix, 1824), Scinax fuscovarius (A. Lutz, 1925), and Lo ocellatus, also captured in Brazil (Souza-Júnior and Martins, 1996). In Corrientes, Argentina, Kehr and Hamann (2003) found specimens of the genus Gyrinicola Yamaguti, 1938 in tadpoles of Pseudis paradoxa (Linnaeus, 1758).

Scinax nasicus (Cope, 1862) is a member of the frog family Hylidae. It is distributed in the following provinces: Jujuy, Salta, Tucumán, Formosa, Chaco, Santa $\mathrm{Fe}$, Santiago del Estero and Entre Rios, in Argentina (Cei, 1980). In Corrientes province, adults and tadpoles were appeared active mainly from October to April. The tadpoles were found in semi-permanent and temporary ponds (Kehr and Duré, 1995).

Fifteen tadpoles were collected in a pond located $30 \mathrm{~km}$ from Corrientes City, in May 2000. They were captured with a $45 \mathrm{~cm}$ diameter dip net. Nematodes were recovered from the intestine, killed in hot water $\left(80^{\circ} \mathrm{C}\right)$, stored in $70^{\circ}$ ethyl alcohol and cleared in lactophenol for further examination. Drawings and measurements were made with the aid of a camera lucida mounted on a Zeiss microscope. The photograph was taken with a camera Nikon FX-35 A (mounted on the microscope). Measurements are given in micrometers (minimum, maximum, followed by mean \pm standard deviation in parentheses).

General: Nematodes with conspicuous sexual dimorphism; body cuticle provided with transverse striations, begins at anterior end, becoming indistinct at tail. Lateral alae present in male. Mouth opening hexagonal, with indistinct lips surrounded by 4 papillae and 2 sessile amphids. Pharynx absent. Oesophagus divided into anterior cylindrical portion and posterior bulb containing valvular apparatus; short istmus. Excretory pore postesophageal.

(1) Centro de Ecología Aplicada del Litoral (CECOAL-CONICET). C.C. 291, (3400). Corrientes. Argentina. Corresponding author: Fax: +54-3783-454421.

E-mail: cynthyaelizabethg@hotmail.com; monika_hamann@yahoo.com. 
Males $(\mathrm{n}=5)$ : total length $1200-1380(1281 \pm 64.3)$ by $84-125(95.8 \pm 17.1)$ maximum width. Cylindrical portion of oesophagus 119.6-190 (143.3 \pm 28.5 ) long by 19.6-30 $(22.8 \pm 4.2)$ wide. Bulb 39.1-60 (47.4 \pm 7.6$)$ long by 41.4-68 (49.0 \pm 10.9$)$ wide. Excretory pore and nerve ring 252-330 (286 \pm 39.9$)$ and 105.8-160 (129.0 \pm 20.7$)$ from anterior end, respectively. Narrow lateral alae beginning at middle level of oesophagus and extending just anteriorly to cloaca. Cloaca situated in a conic prominence with 3 pairs of papillae: 1 pair precloacal, 1 pair postcloacal and a third pair ventrally located in a short tail (Fig. 1). Distance from cloaca to end of the tail 92-130 (106.5 \pm 16.2$)$. Single spicule; length of spicule: $29.9-50$ (37.6 \pm 7.6$)$. Gubernaculum absent.

Females $(n=9)$ : total length $1875-5770(4205 \pm 1179.4)$ by $255-520(386.6 \pm 88.1)$ maximum width. Cylindrical portion of oesophagus 348-550 (410.4 \pm 62.7 ) long by 34.5-54 (46.0 \pm 6.1$)$ wide. Bulb 92-140 (111.1 \pm 17.8$)$ long by 98.9-160 $(127.8 \pm 20.0)$ wide. Excretory pore and nerve ring 450-1200 (935.5 \pm 220.4$)$ and 138-180 (151.0 \pm 12.4) from anterior end. Lateral alae absent. Distance of the vulva from anterior end 1650-2800 (2030 \pm 353.6$)$. Anus 390-700 (576.9 \pm 91.3$)$ from posterior extremity. Long and slender tail. Tail length 315-600 (494.5 \pm 94.2$)$. Didelphic and prodelphic. Eggs assymetrical and triangular in cross-section, 100-130(109.5 \pm 11.2$)$ long by 50.682 (58.9 \pm 9.9) wide (Fig. 2). Operculum of egg elliptical and subpolar. Operculum 20$30(24.8 \pm 3.9)$ long by $7-15(11 \pm 2.6)$ wide.

\section{Taxonomic summary}

Host: Scinax nasicus (Cope, 1862)

Site of infection: intestine.

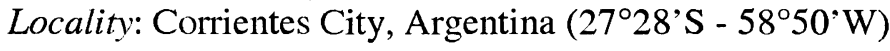

Specimens deposited: Helminthological Collection of Centro de Ecología Aplicada del Litoral (2 - CECOAL 01052305-06; 2 O' CECOAL 01052354-56).

\section{Infections indices}

Number of parasites: 23

Prevalence: $66 \%$

Mean Intensity: $1.53 \pm 1.30$

Minimum and maximum: 1 - 4

Morphological characteristics and dimensions of Argentine specimens of $G$. chabaudi conform closely to previous descriptions (Araujo and Artigas, 1982; SouzaJúnior et al., 1991; Souza-Júnior and Martins, 1996). The presence of two uteri (one dorsal and the other ventral) in female specimen of $G$. chabaudi was clearly seen (Souza-Júnior and Martins, 1996).

The finding of G. chabaudi in S. nasicus in Argentina increases the geographical distribution of this species in South America. 


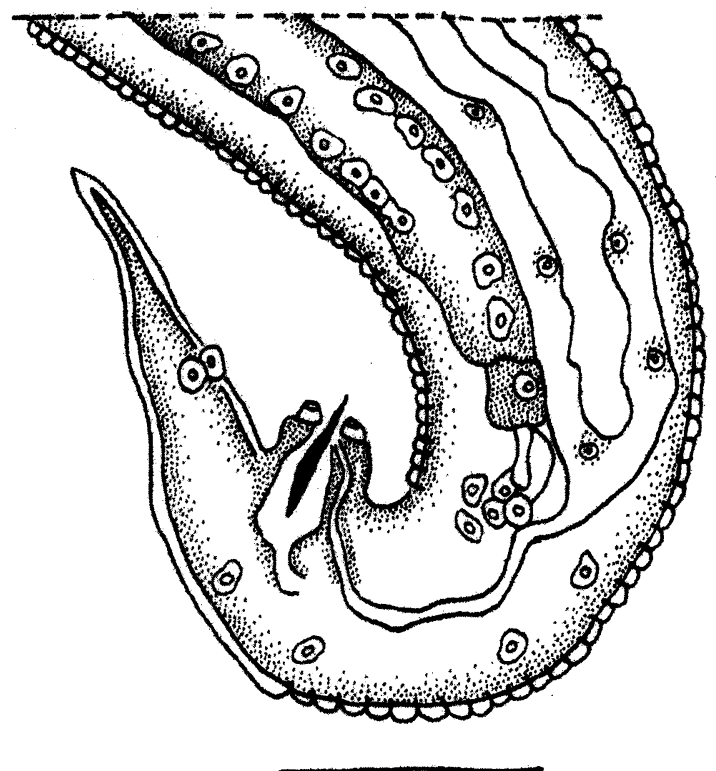

Fig. 1: Gyrinicola chabaudi Araujo and Artigas, 1982: posterior end of male. Lateral view. Bar $=100 \mu \mathrm{m}$.

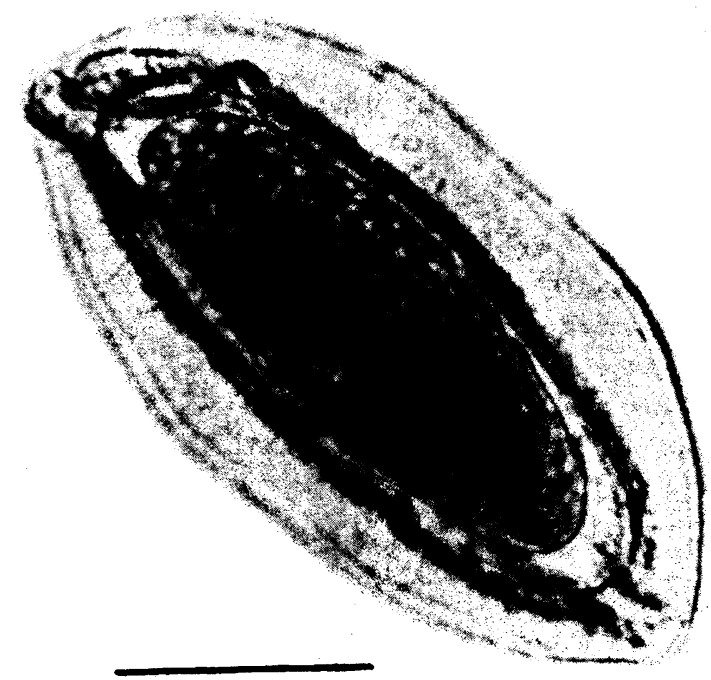

Fig. 2: Gyrinicola chabaudi Araujo and Artigas, 1982: Egg. Bar $=55 \mu \mathrm{m}$.

\section{ACKNOWLEDGMENTS}

This work was partially supported by Consejo Nacional de Investigaciones Científicas y Técnicas (CONICET) from Argentina, through grant PIP 2945 to M.I. Hamann. 


\section{REFERENCES}

Araujo, P. and P.T. Artigas, 1982. Gyrinicola chabaudi n. sp. (Nematoda, Pharyngodonida), oxiurídeo encontrado en girinos. Mem. Inst. Butantan, 44/45: 383-390.

CEI. J.M., 1980. Amphibians of Argentina. Monit. Zool. Ital. (n.s.) Monog. 2: 1-609 p.

KeHr, A.I. and M.I. Duré, 1995. Descripción de la larva de Scinax nasica (Cope, 1862) (Anura, Hylidae). Facena, 11: 99-103.

KeHR A.I. and M.I HamanN, 2003. Ecological aspect of parasitism in the tadpole of Pseudis paradoxa from Argentina. Herpetological Review, 34 (4): 336-341.

SOUZA-JÚNIOR F.L., C.W.O. SouZA and M.L. MARTiNs, 1991. Gyrinicola chabaudi Araujo and Artigas, 1982 (Nematoda: Pharyngodonidae). Description of male specimens collected from tadpoles. Rev. Brasil. Biol., 51: 585-588.

SOUZA-JÚNIOR F.L. and M.L. MARTins, 1996. A redescription of Gyrinicola chabaudi Araujo and Artigas, 1982 (Nematoda: Pharyngodonidae), a gastrointestinal parasite of tadpoles. Rev. Brasil. Biol., 56 (1): 19-25.

Recibido/Received/: 24-May-05 Aceptado/Accepted/: 30-Mar-06 